Debreceni Egyetem, Természettudományi Kar, Szervetlen és Analitikai Kémiai Tanszék* Debreceni Egyetem, Fogorvostudományi Kar, Bioanyagtani és Fogpótlástani Tanszék** Debreceni Egyetem, Ortopédiai Klinika***

\title{
Fogászatban alkalmazható aerogél alapú bioaktív anyagok előálítása és sajátosságai
}

\author{
DR. LÁZÁR ISTVÁN*, KUTTOR ANDREA**, GYŐRI ENIKŐ*, VERES PÉTER*, \\ DR. FÁBIÁN ISTVÁN*, MANÓ SÁNDOR***, DR. HEGEDÜS CSABA**
}

\begin{abstract}
Számos anyagot vizsgáltak az elmúlt időszakban, amelyeket a különböző eredetű csonthiányok pótlására fejlesztettek ki a fogászatban, illetve a szájsebészetben. Egy új szintetikus anyagcsalád az aerogél, amely különleges tulajdonságainak köszönhetően az utóbbi évtizedben az orvosbiológiai kutatásokban is egyre nagyobb szerepet kap. Jelen munka célja, hogy bemutatásra kerüljön a szilika aerogél előállítása, valamint jellemző tulajdonságai, mint például porozitásának, sűrúségének változása hőkezelések hatására. Eredményeink alapján a szilika aerogélek mint bioaktív mátrixok potenciálisan felhasználhatók a fogorvosi, szájsebészeti csontpótlásban is.
\end{abstract}

Kulcsszavak: aerogél, szilícium-dioxid, biokerámiák, csontpótlás

\section{Bevezetés}

A spontán módon nagyon lassan vagy egyáltalán nem gyógyuló csontdefektusoknál a hiányzó csontszövet pótlására az utóbbi évtizedekben egyre elterjedtebben használnak szintetikus vagy félszintetikus anyagokat [3]. A legismertebb és szélesebb körben használt szintetikus anyagok a hidroxi-apatit $(\mathrm{HA})$ és a $\beta$-trikalcium-foszfát (TCP), amelyeken alapuló csontpótló anyagok felhasználásának tapasztalatairól hazai, és külföldi szerzők is beszámolnak $[8,18]$.

A legutóbbi két évtized kutatásai igazolták, hogy a vízoldható ortoszilikát ion esszenciális szerepet játszik a csontszövetek regenerációjában, a megfelelő csontsürüség kialakulásában [7] azáltal, hogy stimulálja az I. típusú kollagén termelését és az osteoblast differenciálódást. A HA és/vagy TCP alapú csontpótló anyagokra is előnyös hatást gyakorolhat egy olyan mátrix, amely aktívan segíti a graftok átépülését $[1,5]$. Erre a célra kiváló lehetőséget biztosítanak az utóbbi két évtized csúcstechnológiáiban alkalmazott anyagok, a szilika alapú aerogélek. Fiziológiás körülmények között bekövetkezö, nagyon lassú oldódásukkal biztosítják a szükséges szilikátkoncentrációt, átjárható anyagukon keresztül pedig lehetővé teszik a szomszédos szövetek számára a szabad anyagcserét, a tápanyag-transzportot. Megfelelő technikával a benövéshez elengedhetetlenül szükséges makropórusok is kialakíthatók, amelyek jelentősen növelhetik az aerogél alapú biokerámiák aktivitását.

$A z$ aerogélek légies megjelenésű, rendkívül kis sűrúségű szilárd anyagok. A leggyakrabban előállított aero- gélek sürüsége tipikusan a $0,05-0,1 \mathrm{~g} / \mathrm{cm}^{3}$ tartományban van. Szintetikus úton, úgynevezett szol-gél eljárással, majd azt követően szuperkritikus szárítással állíthatók elő. Készülhetnek szervetlen oxidokból, természetes vagy mesterséges polimerekből, bioanyagokból, vagy ezek hibridjeiből, kompozitjaiból. Szerkezetükre jellemző, hogy a bennük található néhány tíz-száz molekula átmérőjü, nagy és egybefüggő mezopórus rendszert standard körülmények között levegő tölti ki (1. ábra).

Szilícium-dioxidból (szilika, $\mathrm{SiO}_{2}$ ) készülnek a legismertebb és leggyakrabban alkalmazott aerogélek. Szilárd vázukban ugyanúgy Si-O-Si-kötések találhatók, mint a kvarcban, azzal a különbséggel, hogy míg a kvarc rácsszerkezete szabályos, minden irányban egymáshoz



1. ábra: Egy szilika aerogél monolit látható az egyik szerző (L. I.) tenyerén 


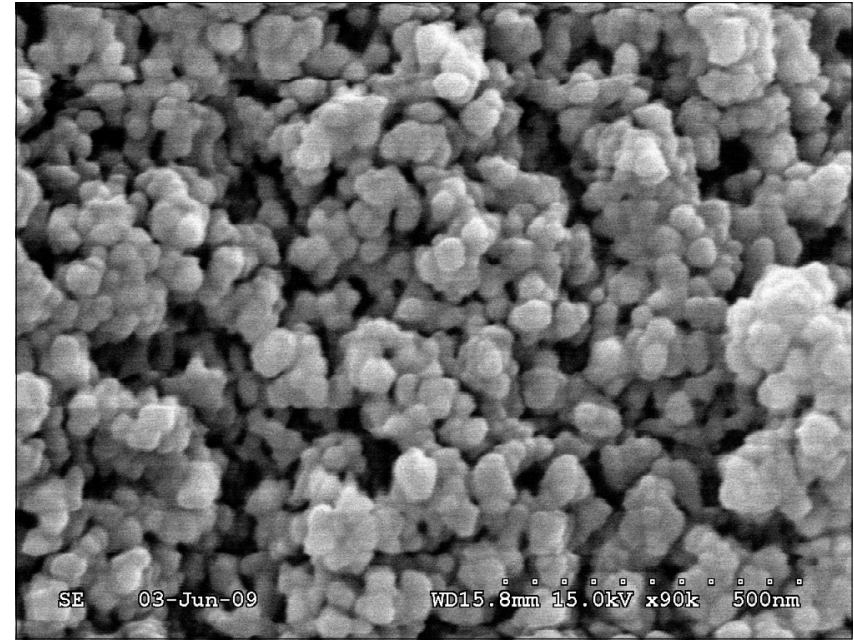

2. ábra: Szilika aerogél törési felületének SEM képe 90000x nagyításban

kapcsolódó $\left[\mathrm{SiO}_{4}\right]$ tetraéderekkel írható le, addig a szilika aerogél amorf struktúrájú, a $\left[\mathrm{SiO}_{4}\right]$ tetraéderek sokkal kevésbé szoros elrendeződésűek. A szintézis kezdetén még szorosabban kapcsolódnak egymáshoz és úgynevezett primer globulákat képeznek, majd a primer globulák lazábban összekapcsolódó gömböcskékké, másodlagos globulákká rendeződnek. A másodlagos

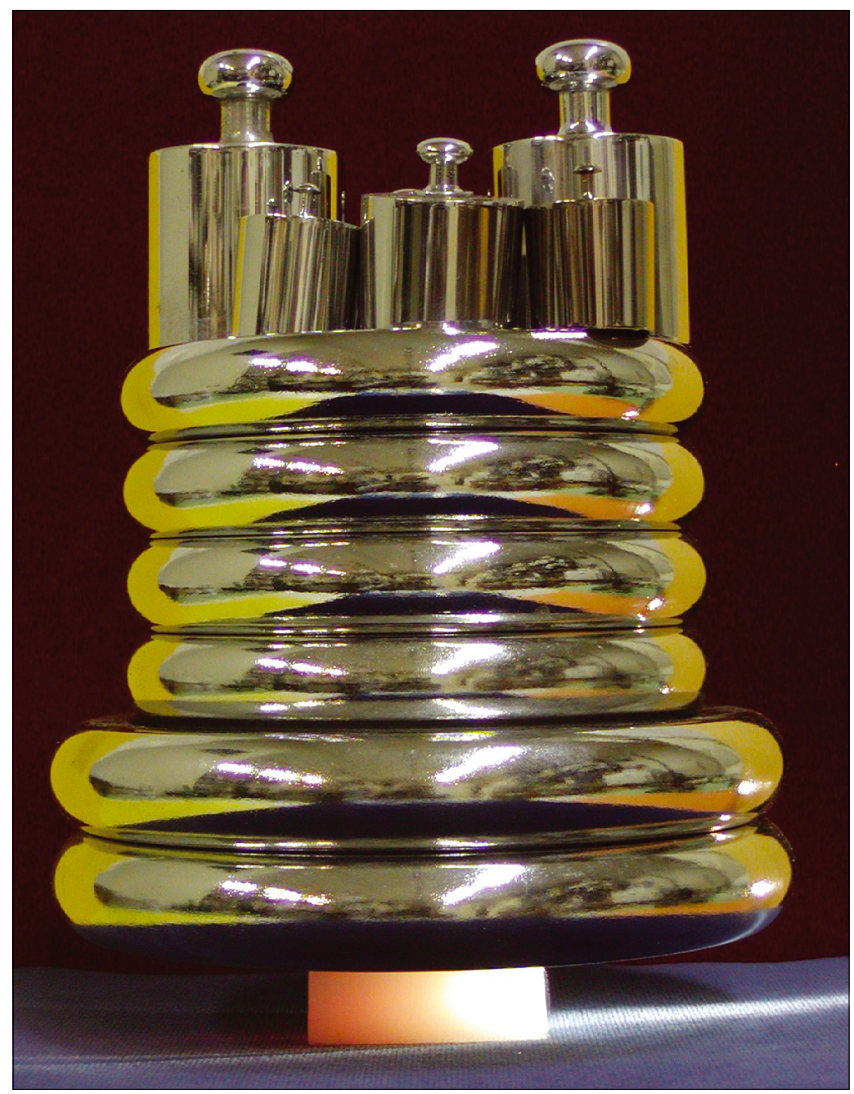

3. ábra: Monolitikus szilika aerogél teherbírásának szemléltetése. A képen egy 2,6 g tömegű aerogélhasáb $9400 \mathrm{~g}$ tömeget, azaz saját tömegének mintegy 3600-szorosát tartja károsodás nélkül. globulák mérete a kémiai reakció során fokozatosan növekszik, végül kialakul egy alkogél, amelynek szuperkritikus körülmények közötti szárításával jön létre az aerogél $[6,13]$. Az aerogélek jellemző, globuláris finomszerkezete figyelhető meg a 2. ábrán látható pásztázó elektronmikroszkópos felvételen. A szilika aerogélek ellenálló képessége az egyenletes nyomóterheléssel szemben meglepően nagy (3. ábra), ugyanakkor ridegek, a monolitikus darabok igen törékenyek.

Egy a Debreceni Egyetemen kifejlesztett új technológia segítségével a szilika aerogél mátrix egyenletes eloszlásban magában foglalhat hidroxi-apatitot és kalciumfoszfátot. Ezek együttesen egy előnyös bioaktivitású, reszorbeábilis anyagot alkotnak, amely az eddigi, állatkísérleti modellel, valamint SAOS-2 sejtekkel nyert eredményeink szerint alkalmas lehet mesterséges csontpótlásra [9, 12, 14].

Az aerogélek jellemző és az utóbbi években legintenzívebben kutatott orvosbiológiai, illetve gyógyszerészeti felhasználásai elsősorban a szabályozott hatóanyag kibocsátású készítmények előállítására vonatkoznak [2, $15,17]$. Ilyen jellegű hibrid aerogél anyagok vizsgálata laboratóriumunkban jelenleg is folyamatban van [16]. A szilika alapú, funkcionalizált aerogélek előnyösen alkalmazhatók ezen túlmenően töltőanyagként poli(-metilmetakrilát) megerősítésére [10], így a jövőben akár csontcementekben, fogtömésekben, vagy protézisekben is felhasználásra kerülhetnek.

Jelen munkánkban bemutatjuk, hogy mennyire széles határok között változtathatók egy aerogél alapú anyag alapvető fizikai tulajdonságai (például a fajlagos felülete, pórusmérete, porozitása) a megfelelően alkalmazott hőkezeléssel, amely a gyakorlatban lehetőséget teremt a céloknak megfelelő tulajdonságú aktív mátrix létrehozására.

\section{Vizsgálati anyag és módszer}

\section{Reagensek és müszerek}

Az aerogél minták szintéziséhez tetrametoxi-szilánt (SigmaAldrich, St. Louis, MO, USA), acetont, ammónia oldatot, és metanolt (Molar Chemicals, Budapest, Magyarország) alkalmaztunk. Oldószerként és reaktánsként kétszer ioncserélt és szénszűrt vizet használtunk. A kész aerogéleket jól záró mintatartó edényekben tároltuk. A szuperkritikus szárítást egy egyedi tervezésű, az MTA Atommagkutató Intézetben készített, nagynyomású (250 bar) tartályreaktorban valósítottuk meg. A minták hőkezelését FHP-12 típusú (Daihan Sci., Korea) programozható felfútésű kemencében végeztük. A porozimetriás mérések a cseppfolyós nitrogén hőmérsékletén, Quantachrom NOVA 2200e (Boynton Beach, Florida, USA) típusú nitrogén adszorpciós poroziméterrel történtek, a térfogatok meghatározásához héliumos feltöltést, a vákuumos minta-előkészítéshez a készülék beépített egységét használtuk. A mérés után a minta tömegválto- 
zását korrekcióba vettük. A pórusméret-eloszlások és a teljes pórustérfogat meghatározását NovaWin 11.0 szoftverrel végeztük.

\section{Szilika aerogél elóállítása}

A szilika aerogélek előállítása általában alkoxi-szilánokból történik, bár ipari célokra ismert a vízüveget mint alapanyagot használó eljárás is [11, 13]. A szol-gél eljárásoknál alkalmazott szilán reagens a leggyakrabban tetrametoxi- vagy tetraetoxi-szilán. Ez utóbbi hidrolízise sokkal lassabban játszódik le, mint a metilszármazéké, így a kívánatos kisebb toxicitása ellenére az in vivo állatkísérleteknél alkalmazott kompozit szerkezetek kialakítására jelenleg kevésbé alkalmas. A szilán reagensből megfelelő katalizátor és víz jelenlétében először kolloidális szilika szol részecskék alakulnak ki, majd ezek növekedésével, egyre szorosabb illeszkedésével létrejön az úgynevezett önhordó gélszerkezet. A gél szerkezetét a szilán reagens minősége, az alkalmazott oldószerelegy összetétele, a katalizátor minősége és mennyisége, a közeg kémhatása, valamint az egyéb jelen lévő komponensek, például felületaktív anyagok alapvetően befolyásolják, a megfelelő $\mathrm{pH}$ beállításával például többé vagy kevésbé elágazó $\left[\mathrm{SiO}_{4}\right]_{n}$-láncok alakíthatók ki. Az elágazásoktól függetlenül azonban minden esetben végső soron a másodlagos globulákból összeálló, egymással erős kovalens kémiai kötéssel kapcsolódó, „borsókőszerü” szerkezet jön létre. A kémiai reakciók ekkor még nem fejeződnek be, azok teljessé tételét, a gél megerősítését az öregítési fázisban végezzük. Ez egy időben elhúzódó folyamat, ami jellemzően egy naptól akár több hétig tarthat. Másodlagos szilán reagensekkel a szerkezetet ebben a fázisban kémiailag módosítjuk. A gélben található oldószerelegyet fokozatosan valamilyen vízmentes szerves oldószerre, tipikusan acetonra cseréljük. A nedves géleket végül szuperkritikus körülmények között, általában szuperkritikus állapotú széndioxiddal szárítjuk ki.

A szuperkritikus szárítás egy különleges eljárás, amely a nedves gél szerkezetének maradéktalan megörzését teszi lehetővé. Levegőn történő, hagyományos szárítás esetén az oldószer felületi feszültségének összehúzó hatása miatt a gélszerú anyagok jelentős mértékben zsugorodnak, töredeznek, aprózódnak, végül úgynevezett xerogélek keletkeznek. A száradás során a gél szerkezete is megváltozik, porozitása, jellemző pórusmérete és pórustérfogata számottevően csökken.

Minden kémiailag tiszta, egy komponensű anyag fázisdiagramján megtalálható egy az anyagra jellemző, úgynevezett kritikus pont, amelyet a hozzá tartozó nyomással és hőmérséklettel jellemzünk. Egy folyadék hőmérsékletét a kritikus hőmérséklet fölé emelve megszünik a határfelület a folyadék- és a gázfázis között, a teljes teret szuperkritikus állapotú közeg tölti ki, amelyet súrűsége a folyadékhoz, hővezető képessége és diffúziósebessége a gázhoz tesz hasonlóvá. A megszűnő határfelület következtében megszúnik a felületi feszültség is, ezért az ilyen állapotban történő szárításkor nem ját- szódik le a fentebb említett zsugorodás, a nedves gélek az eredeti szerkezetük megőrzésével száríthatók ki. Az eljárás bármilyen oldószer esetén használható, ma azonban a széndioxidot használjuk a leggyakrabban, mert nem tüzveszélyes, környezetbarát, könnyen regenerálható, kritikus pontja $\left(73,8 \mathrm{bar}, 30,9^{\circ} \mathrm{C}\right)$ pedig technikailag viszonylag könnyen meghaladható.

$A z$ itt bemutatott aerogél szintéziséhez két oldatot készítettünk, amelyek összetétele a következő volt: „A” oldat: $12,0 \mathrm{ml}$ metanol, 3,00 ml tetrametoxi-szilán, „B” oldat: $12,0 \mathrm{ml}$ metanol, 3,00 ml desztillált víz, 2,00 ml 25\%-os ammóniaoldat. A két oldat elegyítése után a reakcióelegyet hengeres műanyag formába öntöttük, ahol 8-10 perc alatt bekövetkezett a gélesedés és térhálósodás. Az így kapott önhordó gélt egy napig a formában öregítettük, majd oldószercserék sorozata után $80^{\circ} \mathrm{C}$ hőmérsékleten, 200 bar nyomáson, a már publikált eljárással aerogéllé szárítottuk [10]. Az így nyert aerogél nem porszerú állagú, hanem az eredeti géllel megegyező alakú és szerkezetú, monolitikus tömb formájában marad meg.

\section{Hőkezelés}

A kiszárított aerogél minta hőkezelése atmoszférikus körülmények között történt, első lépésben $500^{\circ} \mathrm{C}$ hőmérsékleten 8 óra alatt kiégettük az esetlegesen jelen lévő illékony és oxidálható komponenseket, majd a visszamaradó $\mathrm{SiO}_{2}$ váz hőkezelését (szinterelését) $100{ }^{\circ} \mathrm{C}$-os lépésekben, lépésenként 3 óra hőntartással végeztük. A mintadarab teljes lehülése után meghatároztuk a geometriai méreteit, a tömegét, és kiszámítottuk a látszólagos sürűségeket, illetve az eredeti mérethez képest bekövetkezett százalékos zsugorodási értékeket. Az egyes hőkezelési lépések során a szomszédos szilanolcsoportok utólagos kondenzációja, a megmaradó alkoxi- és szilanolcsoportok alkoholkondenzációja játszódik le, ami kis mértékű tömegveszteséget eredményez.

\section{Porozimetria}

Az aerogélminta $\mathrm{H}$ és $\mathrm{S}$ állapotának porozitását nitrogén adszorpciós méréssel, $77,3 \mathrm{~K}$ hőmérsékleten ha-

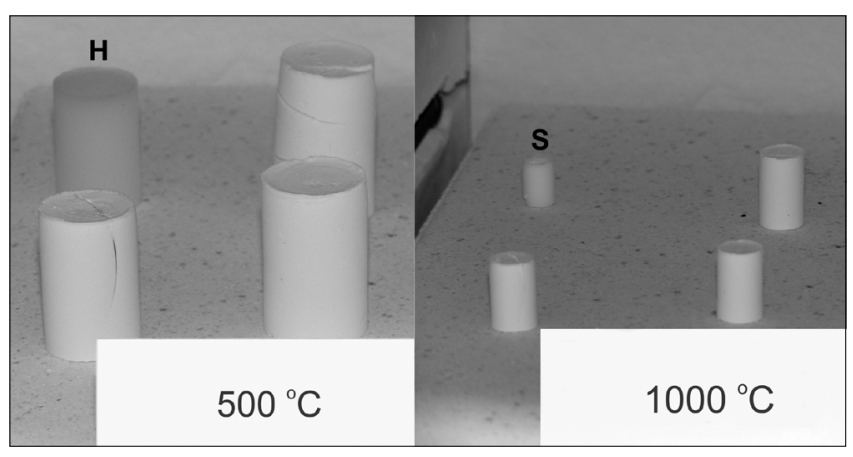

4. ábra: Szilika aerogél $(\mathrm{H}, \mathrm{S})$ és további aerogél-TCP-HA kompozitok

magas hőmérsékleten bekövetkező zsugorodásának szemléltetése. Az ábrán bal oldalon, hátul van az a natúr szilika aerogélmonolit $(\mathrm{H})$, amelynek termikus viselkedése az $\mathrm{S}$ állapot eléréséig az 5. ábrán lévő grafikonokon látható. 


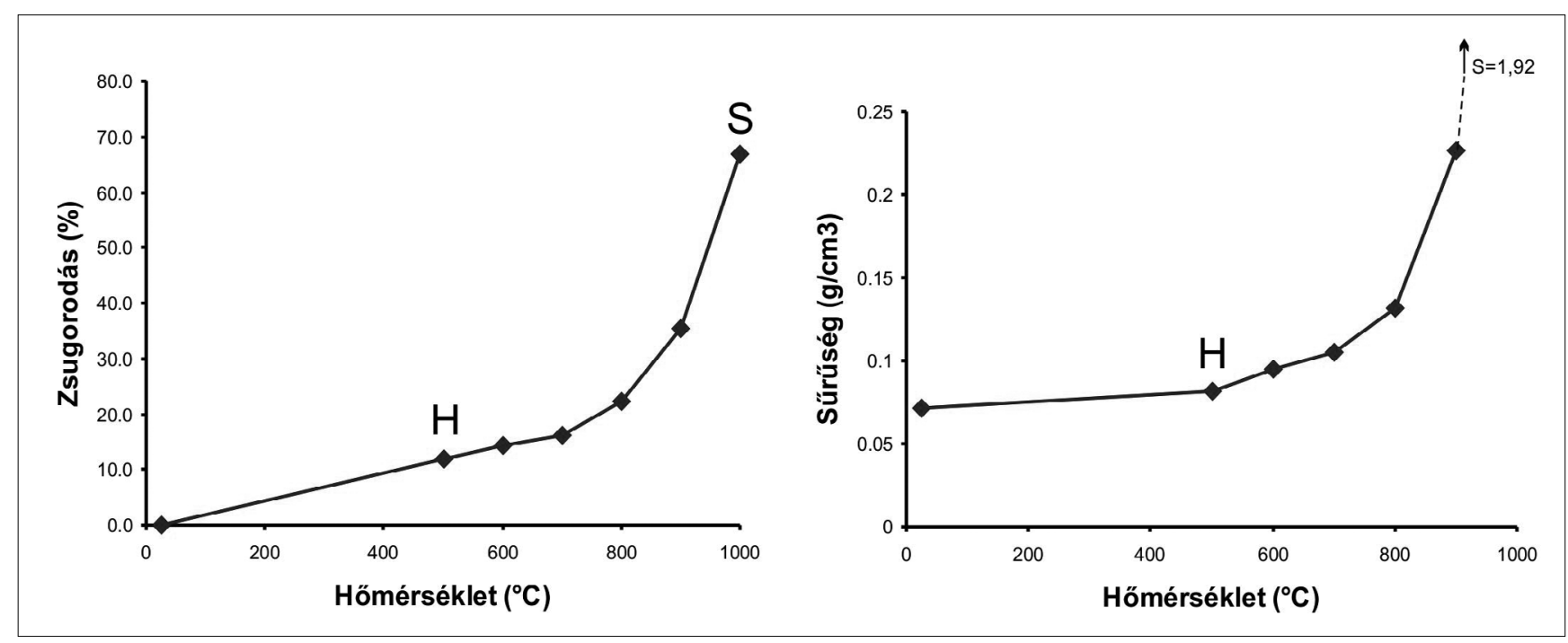

5. ábra: Szilika aerogél százalékos zsugorodása és sűrüségnek változása az egymást követő szinterelési lépéseknél alkalmazott hőmérséklet függvényében.

$\mathrm{H}$ jelzi az $500{ }^{\circ} \mathrm{C}$-on hökezelt, S pedig az $1000^{\circ} \mathrm{C}$-on szinterelt gélekhez tartozó adatokat.

A jobb oldali grafikonon a jobb láthatóság kedvéért csupán jelezzük az $S$ állapothoz tartozó értéket.

tároztuk meg, a mérés előtt a mintát nagy vákuumban, $200{ }^{\circ} \mathrm{C}$ hőmérsékleten 17 órán át kondicionáltuk.

\section{Eredmény}

A 4. ábrán bemutatásra kerülő, $H$ jelú aerogélminta repedésmentes, monolitikus szerkezetű volt, aminek elérése meglehetősen nehéz feladat. Még a szuperkriti-

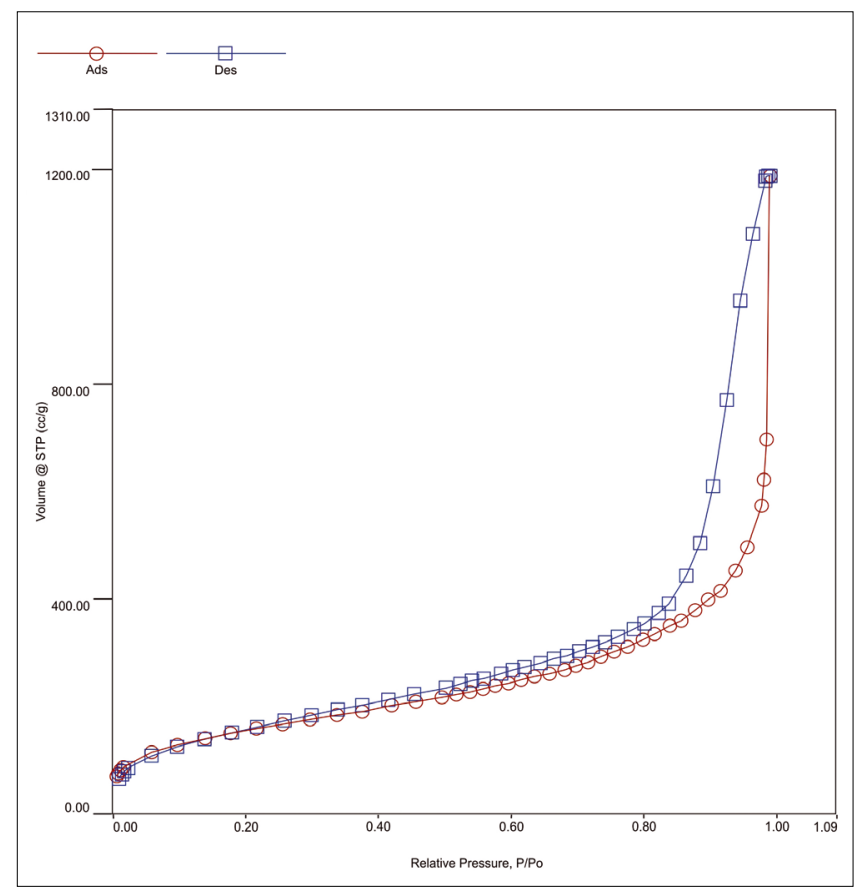

6. ábra: A H állapothoz tartozó minta nitrogén adszorpciós és deszorpciós izotermái $77,3 \mathrm{~K}$ hőmérsékleten,

a realatív nyomás függvényében. Mérés előtt a minta 0,1 mbar alatti nyomáson, $200{ }^{\circ} \mathrm{C}$ hömérsékleten 17 óráig volt kondicionálva. kus szárítási fázisban is történik kémiai változás (kondenzáció), ami a belső és külső régiók esetenkénti egyenetlen zsugorodását, belső feszültség kialakulását okozza. A gél kémiai összetétele mellett jelentős hatást gyakorolnak a viselkedésre a jelenlévő más komponensek, így például a bioaktív adalékanyagok is. Ezek hidrolitikus és termikus viselkedése elősegítheti, vagy megakadályozhatja a repedések kialakulását. A 4. ábrán mindkét viselkedésre látható példa.

A magasabb hőmérsékleten bekövetkező zsugorodás miatt az aerogélminta mérete folyamatosan csökkent, $500^{\circ} \mathrm{C}$ és $900^{\circ} \mathrm{C}$ közötti tartományban a zsugorodás még viszonylag lassú, $900^{\circ} \mathrm{C}$-tól kezdődően azonban egyre nagyobb mértékú, ami a kb. $950^{\circ} \mathrm{C}$ körül meginduló exoterm, felületcsökkenéssel egybekötött, lassú viszkózus folyásnak tulajdonítható. A hőkezelés során tömegveszteség is bekövetkezik, ami az egymás közelében lévő szilanolcsoportok kondenzációs reakciójának eredménye. E két hatás együttesen nagyon jelentős sürüségnövekedéshez vezet, az $\mathrm{S}$ minta esetén a látszólagos sűrüség értéke eléri az $1,92 \mathrm{~g} / \mathrm{cm}^{3}$-t, ami közelít a természetes kvarc $2,65 \mathrm{~g} / \mathrm{cm}^{3}$-es sürüségéhez. Nem meglepő tehát, hogy az $\mathrm{S}$ minta porozitása már kicsi, a benne lévő pórusok a mikropórusok $(\mathrm{d}<2 \mathrm{~nm})$ tartományába tartoznak. Az általunk alkalmazott mérési módszer - bár jelzi a mikropórusok jelenlétét - azok pontos térfogatának meghatározására nem alkalmas. A zsugorodási és sürüségváltozást reprezentáló görbék az 5. ábrán találhatók. Jól látható, hogy nagyon jelentős méretváltozás következik be magasabb hőmérsékleten, az aerogélminta az eredeti méretének mintegy $30 \%$-ára zsugorodott $1000{ }^{\circ} \mathrm{C}$ hőmérsékleten, ugyanakkor a változás a görbe alapján jól tervezhető. $A z S$ állapotban lévő minta keménysége már nagyon nagy, ami összefügg a sürüség még intenzívebb növekedésével, míg a $\mathrm{H}$ állapotú minta nagyon sérülékeny. 


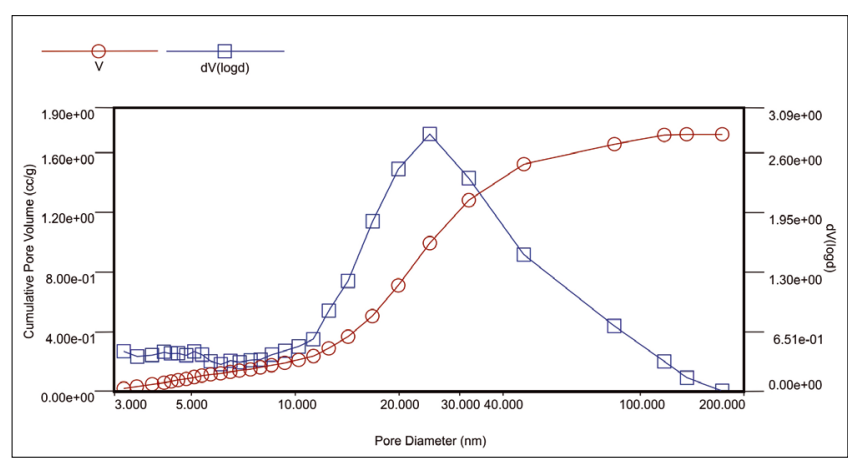

7. ábra: A H aerogél minta nitrogén adszorpciós izotermáiból BJH eljárással meghatározott pórusméret eloszlási diagramja (kék) és kumulatív pórustérfogata (piros) a pórusátmérő függvényében. A teljes pórustérfogat $1,72 \mathrm{~cm}^{3} / \mathrm{g}$, a jellemző pórusátmérő $24,5 \mathrm{~nm}$.

A 6. és 7. ábrán a H jelzésú aerogél adszorpciós és deszorpciós izotermája látható, a hiszterézis hurok jelenléte kvalitatív módon is egyértelmúen jelzi a mezopórusos szerkezetet. A jellemző pórusméret kb. $24,5 \mathrm{~nm}$. Az $5 \mathrm{~nm}$ alatti régióban megfigyelhető emelkedés számottevő további pórustérfogatra utal, a számátlag pórusátmérő mintegy $3,19 \mathrm{~nm}$. A BJH-módszerrel számított fajlagos felület nagyon nagy, $388 \mathrm{~m}^{2} / \mathrm{g}$, ami csak az aerogélekre, illetve az aktív szenekre jellemző tartományban van.

Az S állapotban lévő minta fajlagos felülete már anynyira kicsi, hogy nitrogén adszorpcióval nem határozható meg, bár az adszorpciós és deszorpciós izotermák különbsége mutatja a mikropórusok jelenlétét. Kis molekulákkal szemben (pl. víz, $\mathrm{CO}_{2}$ ) az ilyen pórusok belseje még hozzáférhető, a hidratált ionok, szerves molekulák többsége azonban már kizáródik azokból.

\section{Megbeszélés}

A bemutatásra került aerogélminta két hőkezeltségi állapota csupán a két szélső értékét képviseli azoknak a rendkívül változatos mechanikai szilárdságú, porozitású és oldhatóságú mesterséges anyagoknak, amelyek szilika aerogél alapon elóállíthatók. A H állapothoz tartozó aerogél mechanikailag sérülékeny, folyékony közeggel mechanikailag még nem kompatibilis, ugyanakkor rendkívüli adszorptív tulajdonságokkal rendelkezik. Az erre az állapotra meghatározott óriási fajlagos felület lehetőséget biztosít a gyakorlat számára egyes gyógyszer-hatóanyagok adszorpciójára, majd szabályozott dinamikájú kibocsátására, gyógyszerhordozóként történő felhasználásra. Az aerogél további hőkezelésével a fajlagos felület csökkenése mellett a szilárdság, terhelhetőség jelentős növekedése figyelhető meg. A $700-800{ }^{\circ} \mathrm{C}$-on hőkezelt minták már kellően erősek ahhoz, hogy ellenálljanak a folyadékkal történő érintkezésnek, mechanikailag elegendően szilárdak a kényelmes kezelhetőséghez, ugyanakkor még nagyon jelentős porozitással bírnak. Az $1000{ }^{\circ} \mathrm{C}$ környezetében keletkező, nagy súrúségú, kerámiaszerủ anyagok különösen teherviselő pozíciókban nyerhetnek felhasználást. Eredményeink összhangban vannak az irodalomban közöltekkel [4].

Az aerogélek nem csak önmagukban, hanem más bioaktív anyagokkal alkotott kompozitjaik formájában is elkészíthetők, az így létrejött anyagok egy lehetséges felhasználásáról a mesterséges csontpótlásban, illetve sejttenyészettel szemben mutatott viselkedéséről korábban már beszámoltunk. A hőkezelésen átesett szilika aerogél alapú anyagok felületének aktív módosítására, utólagos funkcionalizálására is lehetőség van. A felületekre például biomolekulák, fluoreszcens markerek köthető́k ki, amelyek tovább gazdagítják a jövőben a felhasználási lehetőségeket.

A közleményünkben nem egy, a gyakorlatban kipróbált megoldást szerettünk volna bemutatni, sokkal inkább egy ígéretes, a jövőben prognosztizálhatóan orvosbiológiai felhasználásra is kerülő különleges anyagcsaládra, az aerogélekre és az azokban rejlő lehetőségekre szerettük volna felhívni a figyelmet.

\section{Köszönetnyilvánítás}

A publikáció elkészítését a TÁMOP-4.2.2.A-11/1/KONV2012-0036 számú projekt és az OTKA K76834 pályázata támogatta. A projekt az Európai Unió támogatásával, az Európai Szociális Alap társfinanszírozásával valósult meg.

\section{Irodalom}

1. Arcos D, Vallet-Regí M: Sol-gel silica-based biomaterials and bone tissue regeneration. Acta Biomater. 2010; 6: 2874-2888.

2. Betz M, García-González CA, Subrahmanyam RP, Smirnova I, KuLOZIK U: Preparation of novel whey protein-based aerogels as drug carriers for life science applications. J Supercrit Fluids. 2012; 72: 111-119.

3. Chevalier J, Gremillard L: Ceramics for medical applications: A picture for the next 20 years. J Eur Ceram Soc. 2009; 29: 12451255.

4. Folgar C, Folz D, Suchicital C, Clark D: Microstuctural evolution in silica aerogel. J Non-Cryst Solids. 2007; 353: 1483-1490.

5. Hing KA, Revell PA, Smith N, Buckland T: Effect of silicon level on rate, quality and progression of bone healing within silicate-substituted porous hydroxyapatite scaffolds. Biomaterials. 2006; 27: 5014-5026.

6. Hüsing N, Schubert U: Aerogels-Airy Materials: Chemistry, Structure, and Properties. Angew Chem Int Ed. 1998; 37: 22-45.

7. Jugdaohsingh R, Tucker KL, Qiao N, Cupples LA, Kiel DP, Powell $\mathrm{JJ}$ : Dietary silicon intake is positively associated with bone mineral density in men and premenopausal women of the Framingham Offspring cohort. J Bone Miner Res Off J Am Soc Bone Miner Res. 2004; 19: 297-307.

8. Kivovics M: „Osteobiol” és a Magyarországon alkalmazott csontpótló anyagok. Fogorv Sz. 2013; 106: 33-38.

9. Kuttor A, Szalóki M, Renre T, Kerény F, Bakó J, Fábián I, LÁzÁr I, Jenel A, Hegedüs Cs: Preparation and application of highly porous aerogel-based bioactive materials in dentistry. Front. Mater. Sci. 2014, 8(1): 46-52. 
10. Lázár I, Bereczkı HF, Manó S, Daróczi L, DeÁk G, Fábián I, et al: Synthesis and study of new functionalized silica aerogel poly (methyl methacrylate) composites for biomedical use. Polym Compos. 2014; megjelenés alatt, DOI 10.1002/pc.22949.

11. Maleki H, Durães L, Portugal A: An overview on silica aerogels synthesis and different mechanical reinforcing strategies. J NonCryst Solids. 2014; 385: 55-74.

12. Manó S, Ferencz G, Lázár I, Fábián I, Csernátony Z: A Slooff-technika nanokompozit csontpótló anyaggal történő alkalmazhatóságának meghatározása biomechanikai vizsgálatokkal. Biomech Hung. 2013; 6: 64-72.

13. Soleimani Dorcheh A, AbBasi MH: Silica aerogel; synthesis, properties and characterization. J Mater Process Technol. 2008; 199: 10-26.
14. Szabó BA, KIss L, Manó S, JónÁs Z, LázÁR I, FÁBián I, et al: Szuperkritikus körülmények között előállított csontpótló aerogél kompozitok vizsgálata állatkísérleti modelleken. Biomech Hung. 2013; 6: 52-63.

15. UlKer Z, ERKEY C: An emerging platform for drug delivery: Aerogel based systems. J Controlled Release. 2014; 177: 51-63.

16. Veres P: Aerogél hibridek elóállítása és vizsgálata, M.Sc. diplomamunka. Debreceni Egyetem, Szervetlen és Analitikai Kémiai Tanszék; 2014.

17. Veronovski A, Knez Ž, NovaK Z: Preparation of multi-membrane alginate aerogels used for drug delivery. J Supercrit Fluids. 2013; 79: 209-215.

18. WANG M: Developing bioactive composite materials for tissue replacement. Biomaterials 2003; 24: 2133-2151.

\section{Lázár I, Kuttor A, Györi E, Veres P, Fábián I, Manó S, Hegedüs Cs}

\section{Preparation and characteristics of aerogel-based bioactive materials used in dentistry}

A variety of bioactive materials have been investigated as substitute materials for diseased or damaged bone tissues in dentistry. The aim of this study was to prepare mesoporous silica containing biomaterials by sol-gel technology. These materials may be combinated with hydroxyapatite and $\beta$-tricalcium phosphate, as bioactive agents. The synthesis and testing of important physical parameters were performed.. Based on these measurements, the silica aerogel can be an applicable material in the dental field in the future.

Keywords: aerogel, silicon-dioxide, bioceramics, bone grafting 